SAND79 2254

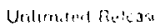

1). 20

\title{
Measurements of Very Large Deformations in "Potash Salt" in Conjunction With an Ongoing Mining Operation
}

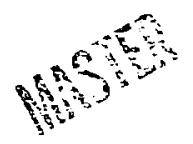

Allan R. Satter, Charles L. Chrieteuset

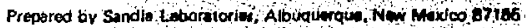

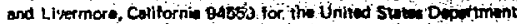
of Energy under Controct DEACO476DPOO7e?
\end{abstract}

Printed June $930^{\circ}$ 
SAND79-2254

Unlinited Release

Printed June 1980

MEASURBIENTS OF VERY IARGE DEFORMATIONS IN "POTASH SALT" IN CONUUNCTION WITH AN ONGOING MINING OPERATION

A. R, Sattler and C. L. Christensen Sandia National Laboratories Albuquerque, New Hexico 8718

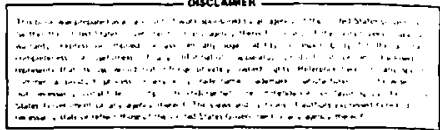


MEASUREMENTS OF VERY LARGE DEFORMations IN "POTASH SalT" IN CONJUNCTLON With AN ONGOING MINING OPERATION*
A. R. Sattler and C. L. Chrlstensen Sandia Nacional Laboratories Albuquerque, New Mexico

\section{AASTRACT}

Room and pillar deformation were wesaured in conjunction with a relatively new type of mining operation in a southeastern New Mexico potagh mine. The extraction ratlo was approxinately 90 percent in a first oining opetation. Due to severe deformations encountered, Instrumentacion had to be developed/modified for thege measurements. This paper concentrateg on experiment design, design of spectal inetrumentation, fleld installation of equipenent, and presentation of che data. Measurements made include extensometers in the plllar, in the floor and ceiling in the room between p1llars, "absolute" level messurements, floor celling closure, and stress (strain) measurements, Assoclated laboratory rock mechanics weasurements of samples from the mine are being done separately.

Two separate room pillar complexes were instrumented. In the ftrst complex, floor-celling deformatlons of approxinately $1 \mathrm{inch/day}$ and plllar deformacions a round 1/2 inch/day were meagured. In the secopd complex, Instrunentation was Installed whlle the plllar was a part of a long wall and the aubsequent sequential mining (long wall-pillar with only one adjoining room on one side - plllar in the middle of room pillar complex) was observed. Data return from this operation was good.

\section{INTRODUCTION}

Sandia Nacional Laboratory has fmplenented an interrelated atrix of experiments performed in galt in support of the Wate Isolation Pilo: Plant (WIPP). The goals of the overall prograw are to obtain aclentific and angineering date applicable to the degign of emplaceent and containaeat syatesa for radioactive waste

-Thie work was aupported by the United States Departaent of Energy. 
disposal in bedded salt formations in southeastern New Mexico and to acquire Inforagtion to resolve generic techalcal issues relevant to Isolation of high-level waste in salt formations.

The work reported herein 18 one phase of this overall program and involves the measurement of room and pillar deformations in a Southeastern New Mexico Potash - mine. The work was a joint effort between Sandla and Mississippl Chemical Company (MCC) to monttor pillar deformations at amblent temperature conditions in an ongolag mining operation. The relatively new mining system employed by Mississ1ppi Chemical Company Involves 90 percent extraction of ore in a first mining operation. The remaining 10 percent is left in the form of a symmetric array of small pillarg which undergo severe deformations over relatively short periods of time. Thio aining approach provides a unique opportunity to monttor large deforwations all the way to fallure, to document the fallure mechanlsms, and to provide detailed data on large deformations due to mining for subsequent comparison with numertcal techniques.

An agreement was made with the MCC whlch allowed Sandia personnel to instrument two rooms and adjacent pillars along the advancing mine face. The mining engineering department of Misalesippi Chemical Company provided support in this effort. Deformation measurements were taken for a number of weeks following each installation.

Large rock sampleg frow appropriate horizons were taken for laboratory determination of material properties. These measured material propertieg are now being used in computer modeling. Both the laboratory data and the modeling work will be reported separately.

Two deparate rooa-pillar coaplexes were inetrunented and the Instrunentation concentrated on asauring the following:

(1) Pillar deforation,

(2) Roof-floor closure between rows of pillars and the plllars themselves.

(3) Extensonetera in the floor and ceiling in the center of the roon to menure geparation of strata due to ulne deformation.

(4) Strese meavuremente in pll1ars (Cook and mee (1978)). 
Sandia designed the overall experiment with additional inputs from the wine. Sandia provided and installed the trangducers (in part Sandia-designed and modified) and recorded the data. All phases of the work were cooperative in that both Sandia and the olne staff made inputg in all areas of the opezation. Trangportation of men, material, and equipment, early preparation of a recording alcove (away from the mining face in a quiet, stable portion of the oine), drilling of extensometer holes, and survey work were mainly done by mine personnel.

The Ingtrumentation deglgn required that the very large (2-4 feet) deformationg to be measured be recorded by aucomated tranoducers. Deformations of the pillars with assoclated roof callapse and floor heave occurred rapidly, on the order of Incheg per veek, and severe deformations occurred within a few weeks. Multipoint extensometers were constructed from commerclally avallable, single channel potentiometer readout gages coupled together with spectal brackets. Relative floor-ceiling room closure was easy to measure with extensometers, but floor and/or celling motion had to be determined separately. A hydraulic level gage was developed and Installed, which peratted separating motions of floor and cetling.

Implementing this activity involved problems associated with instrumentation of an experimental ares in proximity to an ongoing mining operation and the aspect of mine safety due to the rapid deformation. In order to record the data at a distance of approximately $1000 \mathrm{ft}$. auay from the ingtrumented pillars, long cable runs, cable Jumpers, and function boxes vere necessary. Automated readouta, using potentlometers (vs. dial gages) were necessary for personnel safety.

This paper reports on highlights of the experiment design, design of epecial instrumentation, field 1nstallation of equipment and presentation of repregencative data.

DISCUSSION

Two wajor experimeats were planned and executed--Small PIllar Experiaenta One and Two. A plan view of the mine where experiments were perforned ls shown in Figure 1. The experibente centered on mesuring the deformation of one of the gnell pillars which remains behind during the alning operation, recording the deformations which take place in the raoms on each side of the pillar and evaluating the 1natruants designed for these tasks. The layout and sequence of the aining 
operation can be seen in Figure 1, whth a geologic profile of the hor izons mined shown in Figure 2.

In each roompillar complex, the plilar chosen for ingtrumentation was as close to the center of the room as passible to animize the effects of barrier or abucment plilars or other boundaries, For the same reason, rooms selected for Instrumentation were chosen well away from barrier or abutment pillara. The area rewaining after olning conolsted of rung of 8 -foot $\times 20$-foot p11lars, 10 feet apart, 60 feet between rows.* The minlmum distance between an instrumented area and any boundary or area differing in mining was about 150 feet for the first room instrumented and about 200 feet for the second room instrumented.

In the second of the two experiments, Mississippl Chemical Mine personnel agreed to mine a long pillar by odtting two cuts becween standard plllars, providing a plllar whose dimensions were $80-$ feet long $\times 10 \mathrm{~m}$ fet wide $\times$ 6-faet high. Th1s provided a more favorable aspect ratio which allowed a two-dimensional plane strain configuration for subsequent computer modeling comparisons instead of threedimensional calculations. Further, it provided more space along its length for lastallacion of 1nstrumencation.

\section{INSTRUNENTATION UTILIZED}

It became clear in the design phase of these experiments that, because of the high extraction ratio in the mining operation with the attendant large and rapid defarmations, there would be problews not normally encountered in field rock mechanics meatureanta. As with wost wining operactons, the transducers had to be 1astalled as soon as possible after mining as the early deformation data are very Important. Manually read (dial) gages vere not an option because instrusented aress became fascessible due to aine affety considerations uithin a few days as the mining operation progresed. Also relative floor-celling motion, weasurable by a floor-ceiling gage, would have to be further analyzed to that ceiling collapse and floor heave can be dfferentlated. The above instrumentation and recording conacraints were met as followa:

-Such extraction of approximately 90 percent of the ore 1ndeed caupes Immediace neasurable deformations. Floor-celling closure atarts at about an inch per day and continues at about this rate for a few weeks until floor and celling touch or are only a few inches apart. 


\section{Extensometer Development/Hodification}

Multipoint extensoweters with automatic readouts capable of measuring very large deformations were not available on a time frame constatent with the mintng schedule. However, single channel potentiometer readout deformation gages useful as floor-cefling dieplacement gages capable of measuring large deformations on the order of one foot are commercially avallable.* These gages were directly utildzed for recording relative floor-celling deformations with mlnor wodifleations (See Figure 3). A complete measurement of the displacement field in the floor and ceiling was accomplished by designing a bracket which utilized several of these Individual potentlometer gages In combination, also shown in Eigure 3 . A more detalled view of the constructed multipoint extensometer is presented in Figure 4. This multpoint extensometer was then 1nserted in the floors and celings of the ingtrumented rooms as well as $\mathrm{I}_{\mathrm{n}}$ instrumented plllars, resulting in deformationtime measurements at alven distances above the roof and below the floor of the room.

Hydraulic Level Gage

In order to determine absolute displacement of roof and floor, a hydraulic level gage accurate to approximately 0.1 inch was used. Use of this gage allowed roof and floor motion to be disinguished. This level gage was on the floor in the middle of the instrumented rooms in each of the two experiments, while the reference reservolr was in a more stable area of the mine (about 500 feet away). A reading of floor motion heave was obtained by observing the level of the reference reservolr.

Celling motion was also obtained at one point by optical survey methoda using

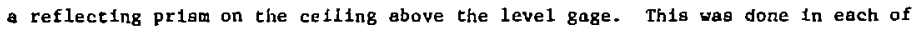
the two roomplliar complexes.

\section{Installacion of Instrumentetion}

Because the inficial plllar deformations were up to cwo inches per day and aafe access could be maintatned only until an adjoining room uas mined, detalled planning of the gage Installation had to be made prior to actual inatallation of rack

*Untts utillzed In this prograd were manufactured by Celesco and Research Incorporated. 
aechanics equipment in the two room-pillat complexes. Cable runs from the data. logger to the mining face (approxlmately $2000 \mathrm{ft}$ ) had to be made, a junction box connected at the end of the cable run and a preliminary check of channels made. When permission was given by Mississippi Chemical Company to actually enter the newly-mined room-pillar complex, transducer installation began imediately and was virtually completed in two to four days with the exception of floor-ceiling gages which would go on the far (unmined) side of the mine face as the mining advanced.

A data acquistion system was installed in a room prepared in a conventionallymined room and pillar area of the mine. This roon was on the other side of a barrfer plllar separating the new mining and the rest of the mine (See Figure 1). It was also reasonably far from other mining activity to be suitable for a base otation for recording, and a staging area for ingtallation of cranaducers.

Cables (twisted shielded pair) * were run between the base gtation and locatlons one room behind the rooms which were mined and instrumented. The cable was fastened to the wall and celling, tylng onto staples set in the mine with a RAM Set stsple gun. Adequate slack was left between ties so the cable would not be snapped by ensuing deformation. A junction box was connected to the cable and checked out.

When the room to be instrumented was made accessible by Mississippi Mine personne1, the junction box was brought inco the room and all transducer connections were made through that box. The local cable runs between the junction box and the transducer runs were made using g four conductor shielded cable.* Upon retreating from a room after the ingtrumentation was installed, a steel table was placed over each of the two junction boxes. These precautions were adequate to prevent loss of data due to crushed or ruptured cable.

Inetrumentation ut1lized in Small P1llar Experiment One was as follows:

(1) E1ght (8) Floor/Celling Convergence Gage日

(2) One (1) 3-point Floor Extensometer at $-27^{\prime},-20^{\prime},-10^{\prime}$

(3) One ( 1 ) 3-point Celling Extensometer at $+30^{\prime},+20^{\prime},+10^{\prime}$

(4) Two (2) 2-point Wall Extensometers at $\left(2^{\prime}, 4^{\prime}\right)$ and $\left(5^{\prime}, 1^{\prime}\right)$

(5) Two (2) Irad Strese Gages

ऋChosen for strength and conventence in recording. 
(6) Ten (10) Break Wire Gages

(7) Three (3) Micro Selsmic Detectors

(8) One (1) Leveling Gage

(9) Two (2) Roof tolt Matrix Installations

Instrumentation Litilized in Experiment Two consisted of:

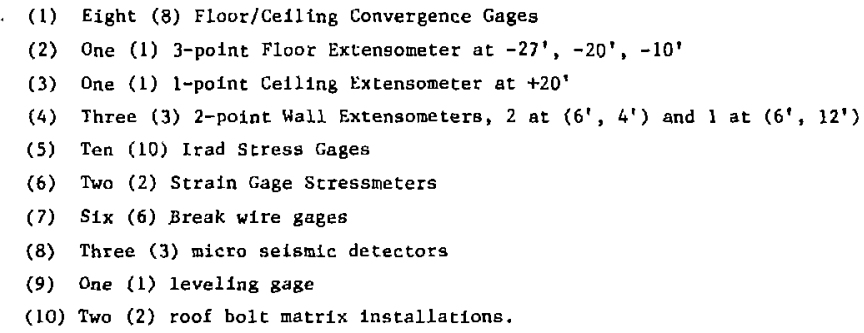

Locations of placement of the various convergence, extensometer ano breakwire gages are indicaced in Figure 5 for Small P1llar Fxperiment 1 and In Figure 6.for Experiment 2. Note particularly the long ("pline strain") vall instrumented in Experiment 2.

Information on the data logger was recorded every hour for two weeks af ter Installing each of the two groups of instrumentation and every three hours until the end of the recording period. Access to the 1nstrumented rooms af ter installation (mainly for photography) lasted only for about a week due to mine safety considerations. The base otation, which contained the data acquiaition system and assoclated circuitry, was visited cwice weekly to remove data and maintain the recording aystem. Long-range photography of the inatrumented areas was continued for approximately two months from a main accessway to that area until even the accessway to the mined-out panels was barced to entry.

RESULTS

\section{Firgt Experiwent}

In the first experiment, Small P1llar Experiment l, where the panela and roon were tined two to three days prior to experiment installation, the floor-ceiling 
closures were about an inch per day for thirty days and slower thereafter. Ce111ng motion accounted for about two-thirds of the wotion and floor heave accounted for the rest. The closure vas falrly uniform in the roon. The pillars provide some local support for the celling at later stages of deformation. The closure at the cencer of the room was similar to the closure between pillars. Floor-celling convergence data from the eight convergenca gages are plotted schematically from a computer printout in Figure 7 for various times, showing the spatially uniform closure rate. (See Figure 5 for gage identification.)

The pillars themselves bulged out as seen schematically from a computer printout in Figure 8 . The extensometer chrough the width of the pillar showed an elongation of one-half Inch per day for 30 days on the outer quarter of the pillar and the half width of the pillar increased about $2 / 3$ of an inch per day for 30 days. The elongation of this ingtrumented pillar vas about two-thirds of an inch per day for 30 days with most of this coming in the outer three-fowrths of the pillar and virtually none coming from the center portion (1/4) of the pillar.

The data from extensometers in the floor and celling showed that up to $30 \mathrm{ft}$. into the rock in each direction vertically there ts to apprectable separation of the strata (F1gure 9).

The level gage and survey data show that in 30 days the floor heave amounts to about eight inches out of a total floor-celling cloaure of 30 inches. The floorcelling convergence data correlate well with the separate floor (level gage) and ceiling (survey) measurements.

Breakuire gages 1ngtalled to detect gross slabblug gave ambiguous data as pillar olabbing occurred virtually on a continuous basia.

Only two channels out of about twenty were damaged and gave apurious readings after the first fifteen days. After 30 days wore of the channels gave anbiguous readinge, probably due to the effects of severe deformations on the extensometer mounts. The signal was lost from only one channel (aiter 40 days) durtng the monitoring period.

\section{Second Experiment}

In the becond experiment, the mining operation was such that the aequence in mining could be better observed by the inscrumintation. The panela were only 9 
hours old when Ingtallation was made 1nto the portion of the long wall which was not to become a pillar unt1l three days later. Floor celling closure transducerg and extensometers into the floor and celling were lngtalled within two days. Only the one adjolning room beyond the $80 \mathrm{fc}$. by $20 \mathrm{ft}$. wall was mined unctl about 50 days later. During this clme, the floor-celling closure rate was slower than in the first experiment. After 50 days, additional cooms were mined beyond the loog wall pillar. Each data chennel (floor-celling closure, pillar deformation and floor heave) showed a distinct inflection (1ncrease) in the deformation rate when this addftional mining was intefaced after three days and 50 days. A typlcal floor-celling convergence gage recording is ghown in Flgure 10. The two inflectiong present corcrespond to the tines when additional wining operations were initiated. These inflections are also visible In Figure 11 , which shows data from a representative whal extensometer recording taken near the outeide of the long wall $\mathrm{ith}_{11}$ Figure 6. (These inflections were seen in virtially all floor-calling, leveling gage and extensometer channels. All chunnels recorded for to days.)

CONCLUDING REMARKS

The large deformations in rooms and Mllars resulcing frow the new high extraction mining method used at Misgissippt Chemical Company were successfully measured. The installation of instrumentation was able to begin prompty after mining the room and pillars espectally in the second experiment. The experiment was conducted with no interruption in the wine production schedule. The sequence of mining was observed very clearly in the extensometer and closure data observed in the second experiment.

The Sandia oodification, adsptation, and fabrication of transducers which messure large deformactons worked satsfactorily.

The hardening rechniques used to protect extensometer anchors, algnal cablea, cable rune, Junction boxes, etc., were adequate. Signala from virtually all critical chanels were recorded without ambiguities during the course of the won1torlng period. Lahoratory rock mechanies testa to deteimine material properthes and the comparative analyses are currently underway (Senseny, Pfeifle and K1081, (1980)). 


\section{ACKNOHLEDGEMENTS}

(1) The authors and Sandia Laboratorieg are grateful for the cooperation and participalion of the Misstssippl Chewical Company In this work. A special acknowledgersent is given to Timothy Hall, Mine Superintendant, and the mining engineering ataff who devoted a great deal of time and nffort in elcuring the success of this venture.

(2) The transducer degign/modiflcations were made by E. S. Ames and C. W. Cook of Sandia Laboratories. J. T. McIlmoyle, Sandia, was in charge of data acquisitian.

(3) This report and the attendant experimen:al results were reviewed and edited by $\tau$ : A. Duffey, Los Alamos fechnical Assoctates, Inc.

\section{BIBT. IOGRAPHY}

(1) Cook, C.W., and Ames, E.S., "Borehole Inclusion Stressmeter Measurenents in Bedded Salt", Proceedings of the 20th Symposium on Rock Mechanics (1978).

(2) Senseny, P.E., Pfelfle, T.W., and Klas1, I.L., "Laboratory and Numerical Studies in Support of the Sandia Small Pillar Experiment Two", RE/SPEC Inc. Report RSI-0012 (1980). (First Interin Report). 


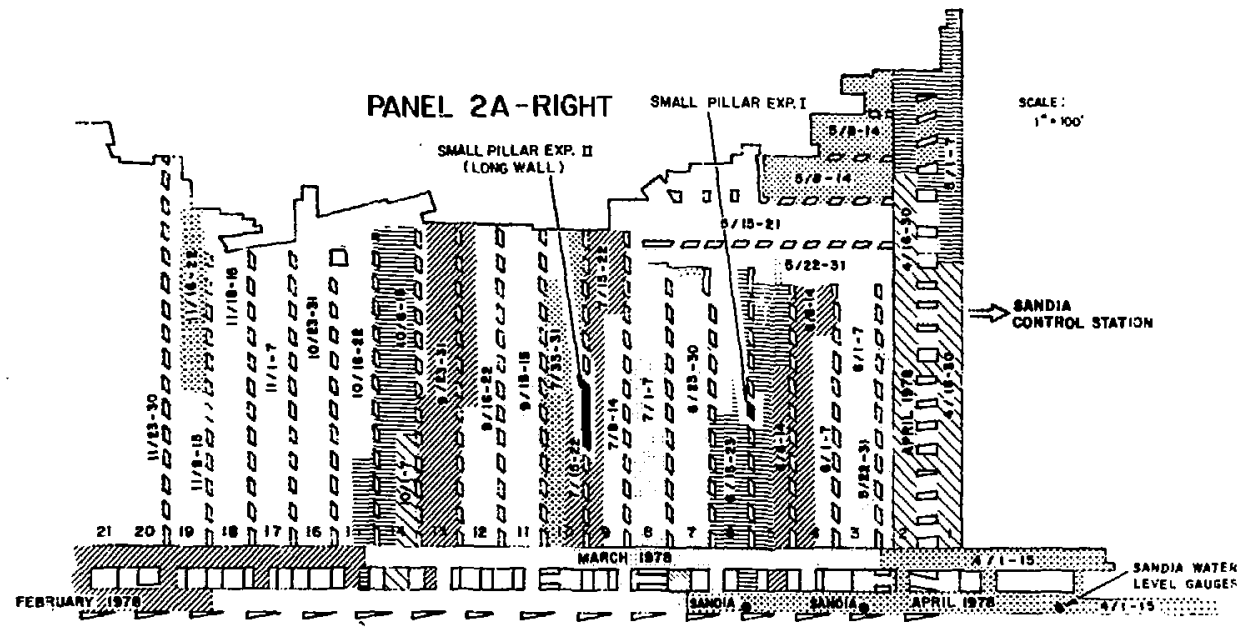

FIEURE 1. PLAN VIEK SHOKING EXPERIMENT IN MISSISSIPPI CHEMICAL CO. MINE 


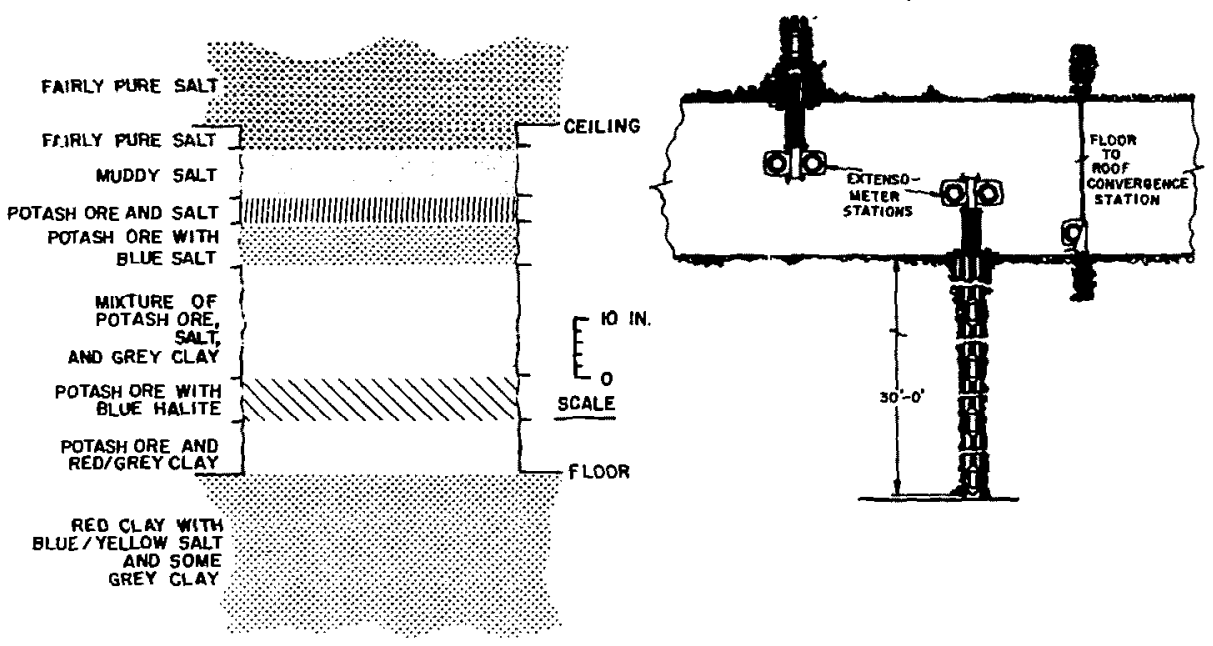

F1GURE 2. GROSS STRATOGRAPEIC CROSS SECTION TAROUGH MINED AREA

FIGURE 3. YIEW OF TYPTCAL EXTENSOMETER AND CONVERGENCE STATIONS 


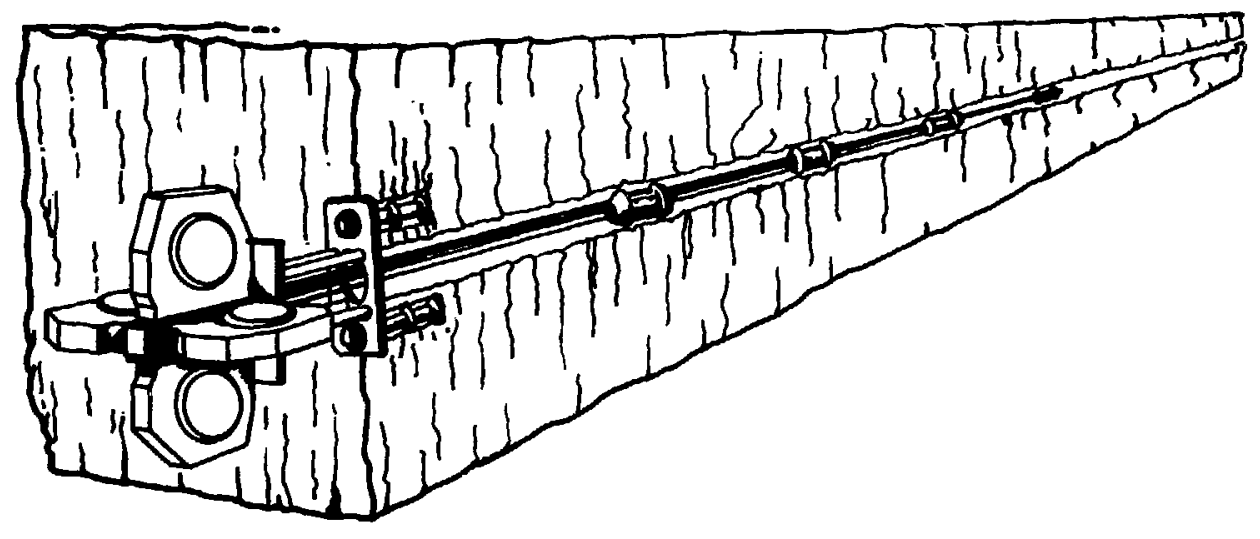

FIGURE 4. MULTIPOINT EXTENSOMETER DESIGN 


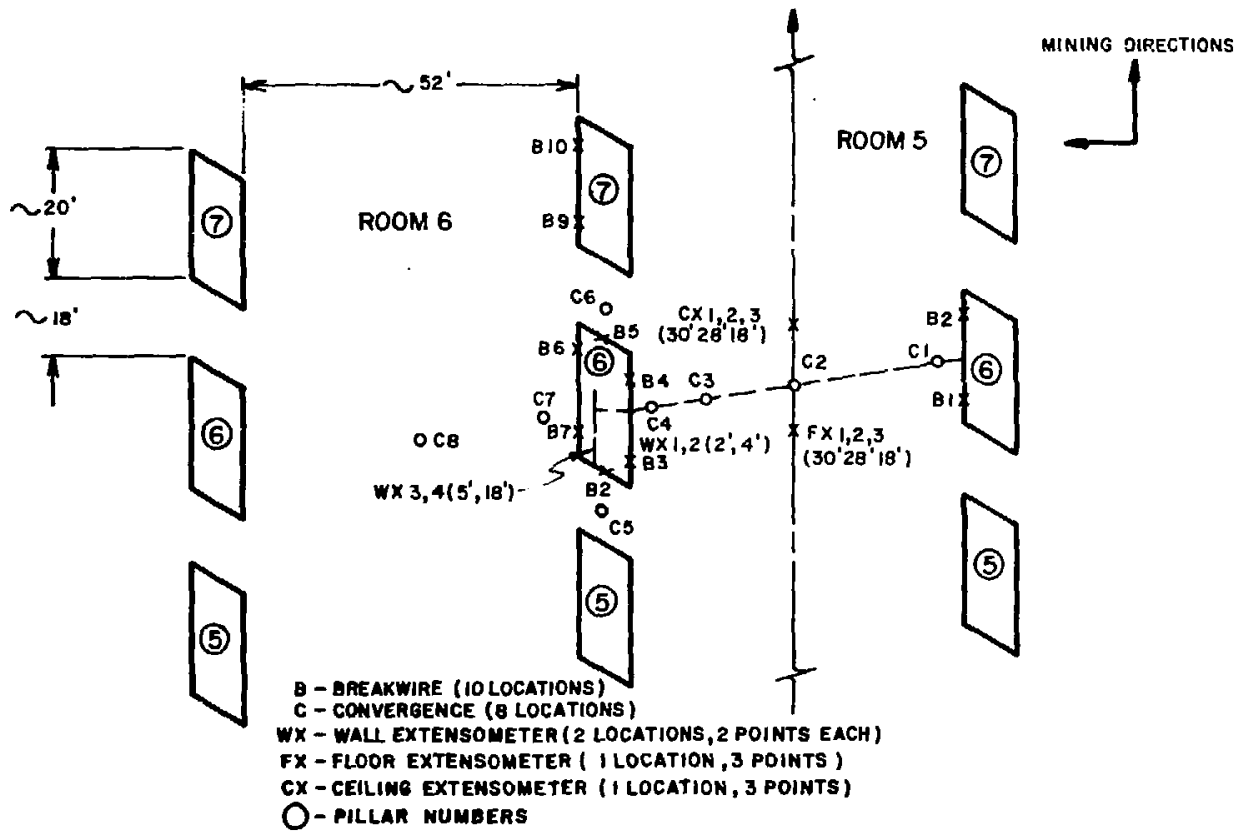

FIGURE 5. SHALL PILLAR EXPERIMENT I MISSISSIPPI CHEMICAL CO 16-22 JUNE 1978 INSTALLATION 


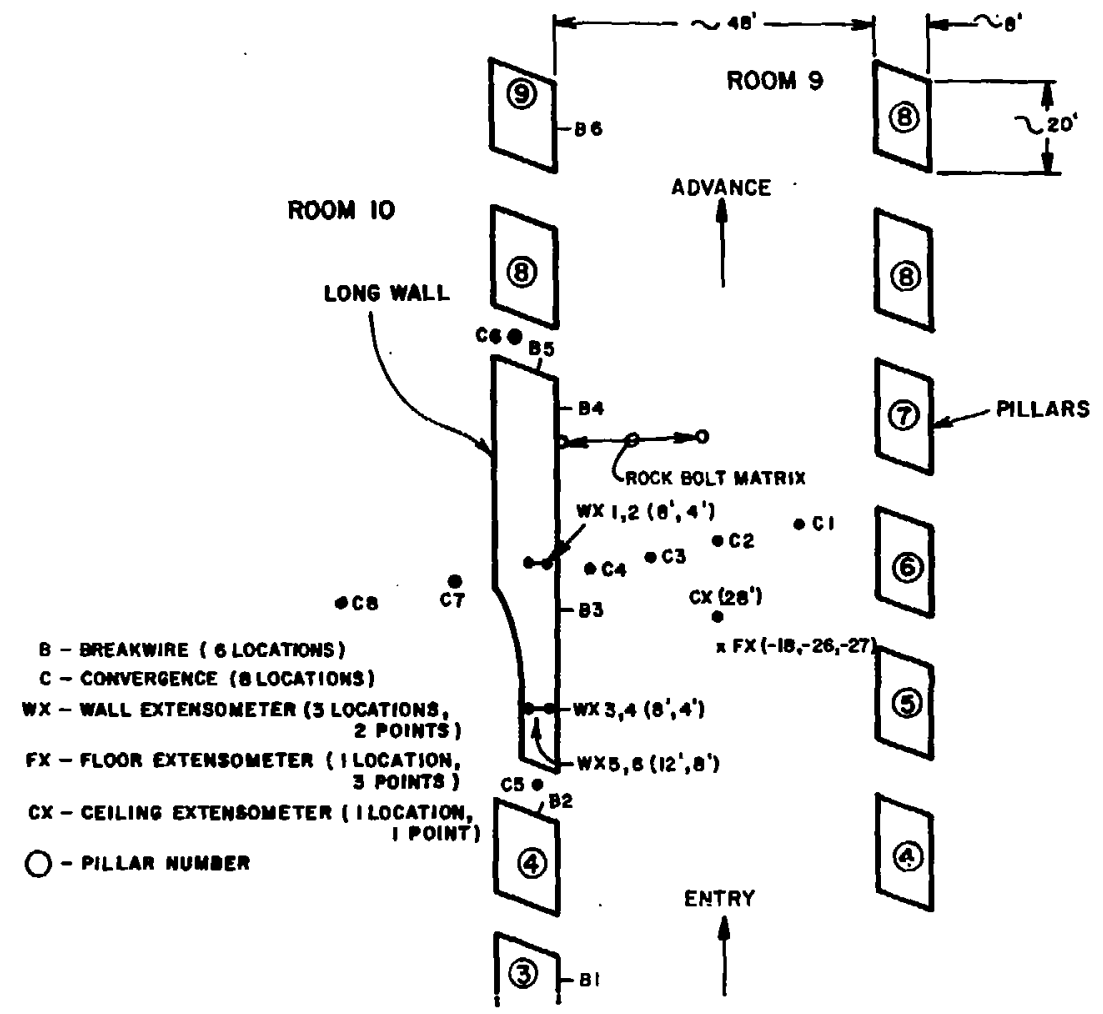




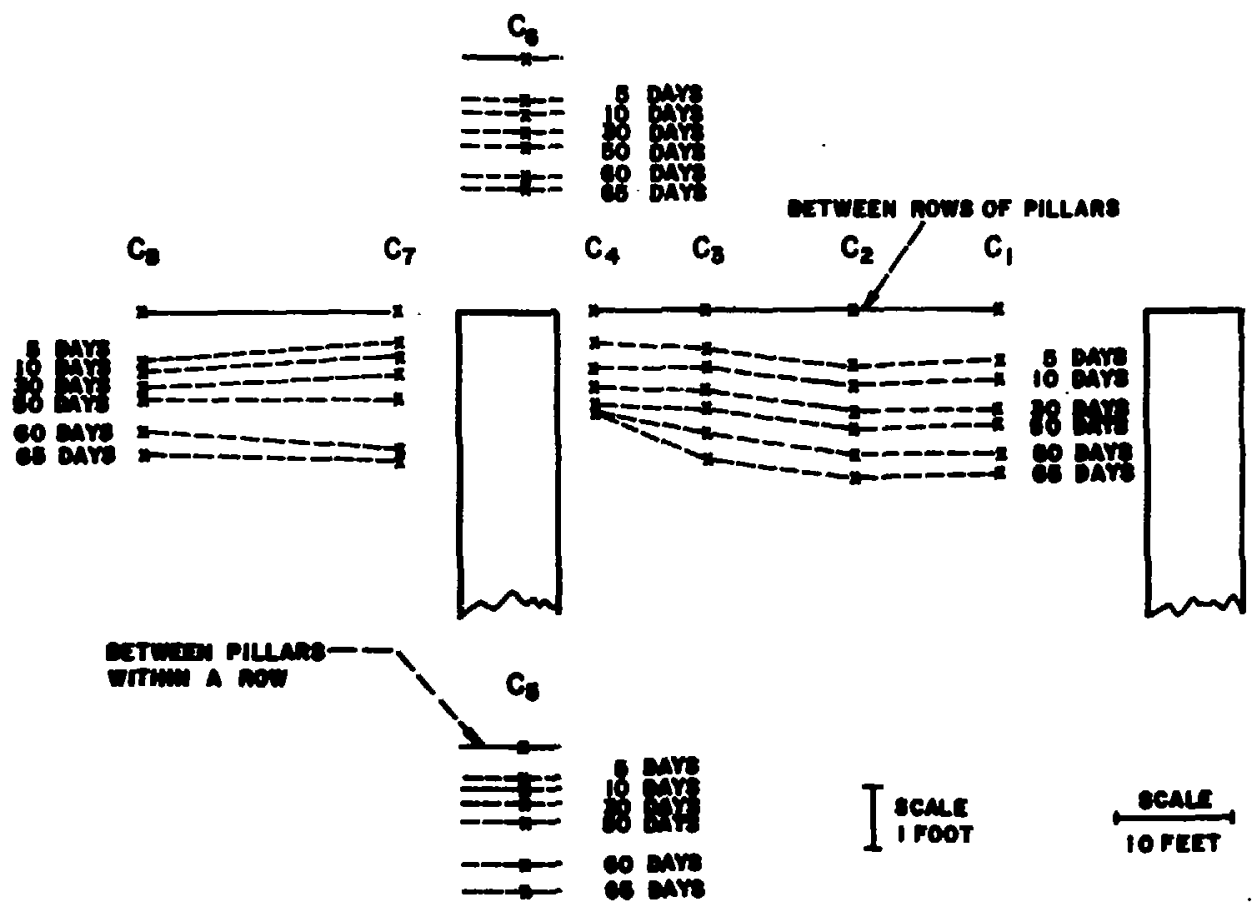

F IGURE 7. SCHEMATIC OF FLOOR-CEILING CONVERGENCE EXPERIMENT I 


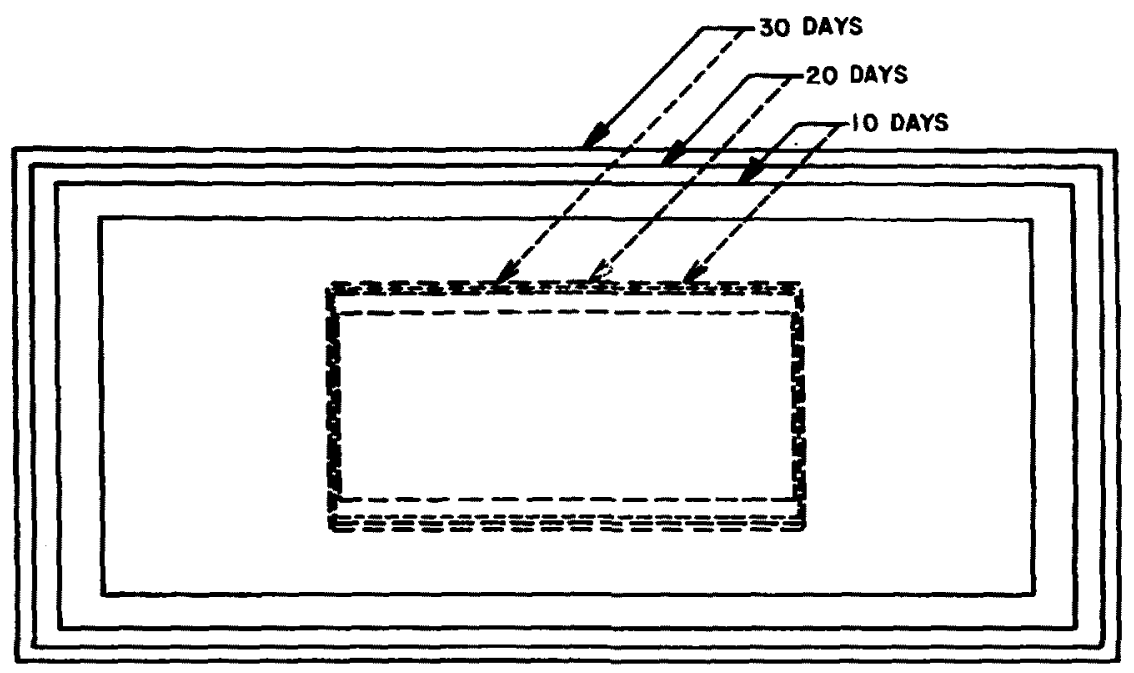

FICURE 8, SCHEMATIC OF PILLAR EXPANSION EXPERIMENT I

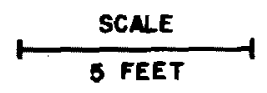




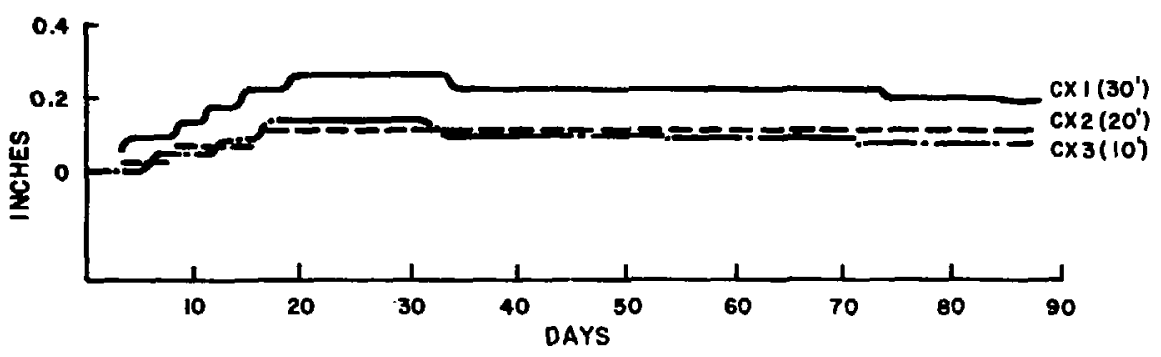

FIGURE 9a. LEILING EXTENSOMETER DATA -- SMALL PILLAR EXPER IMENT I

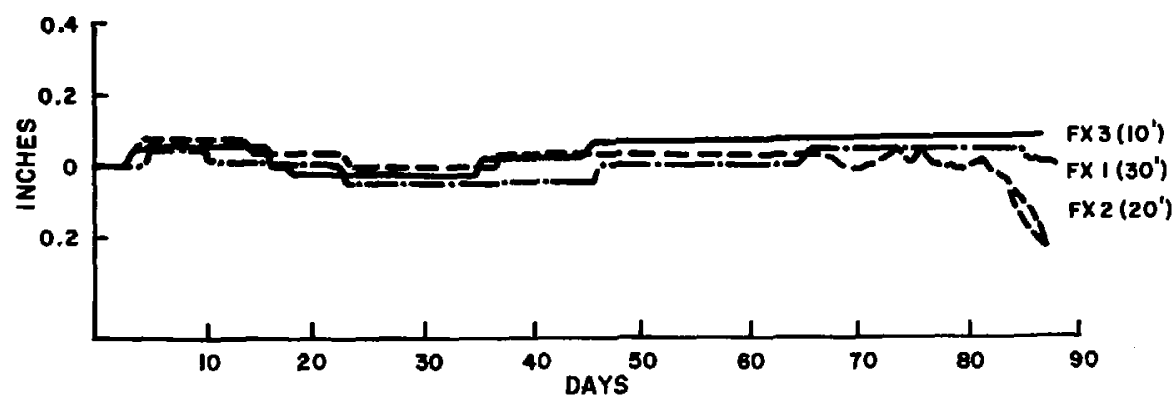

FIGURE 9b. FLOOR EXTENSOMETER DATA -- SMALL PILLAR EXPERIMENT I 


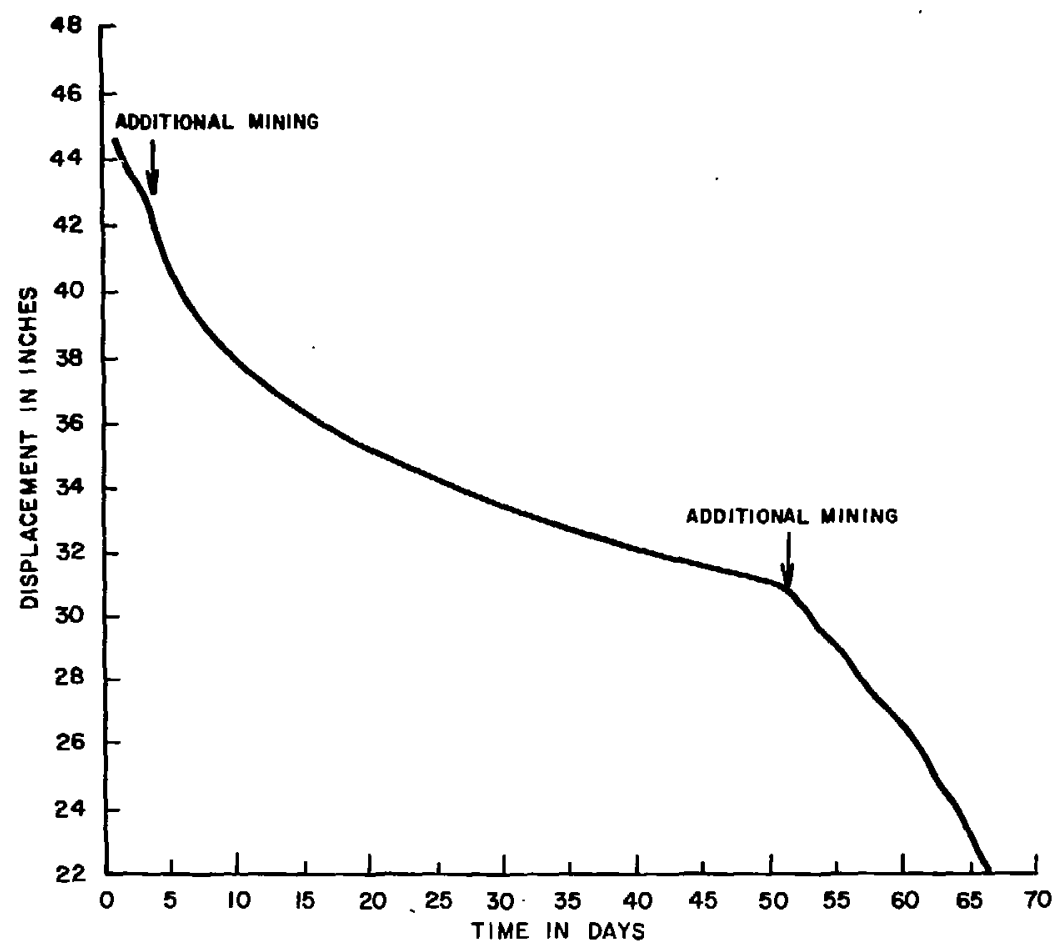

FIGURE 10, TYPICAL FLOOR/CEILING CONVERGENCE RECORDING (EXPERIMENT 2, GAGE C2) 


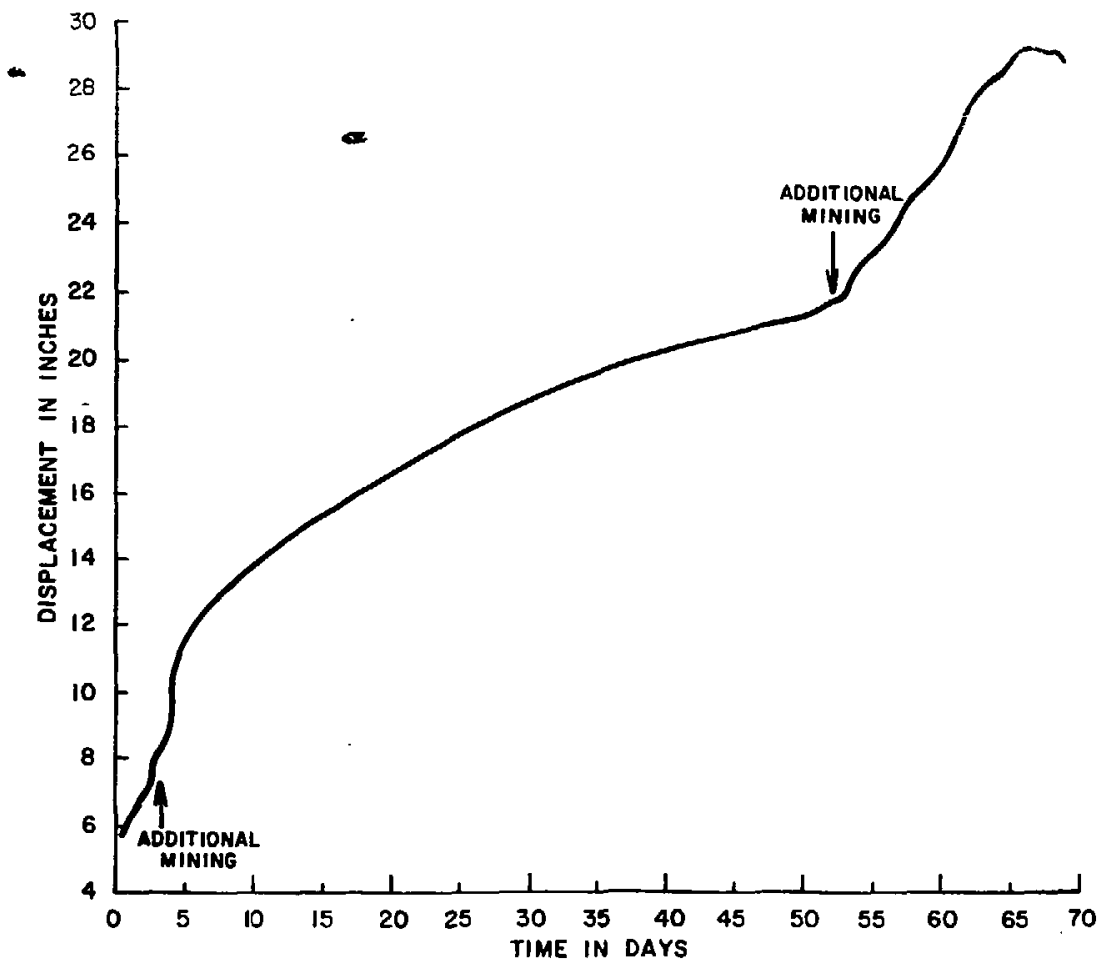

$-1$

FIGURE 11. TYPICAL WALL EXTENSOMETER RECORDING (EXPERIMENT 2, GAGE WX 2) 